\title{
Reconstructing Latitudinal Shifts of the Southern Westerlies from Marine Sediment Studies along the Chilean Continental Margin
}

Compared to the North Atlantic region, high resolution paleoclimate studies from mid-latitudes of the Southern Hemisphere are still rare despite the fact that this part of the world plays a major role in understanding the interhemispheric pattern of climate change both during the last glacial cycle and the Holocene. A key region to study past climates of the Southern Hemisphere midlatitudes is undoubtedly southern South America. This fact has lead to considerable effort by the terrestrial paleoclimate community, e.g. within the PAGES PEP I transect (Markgraf et al., 2000). However,

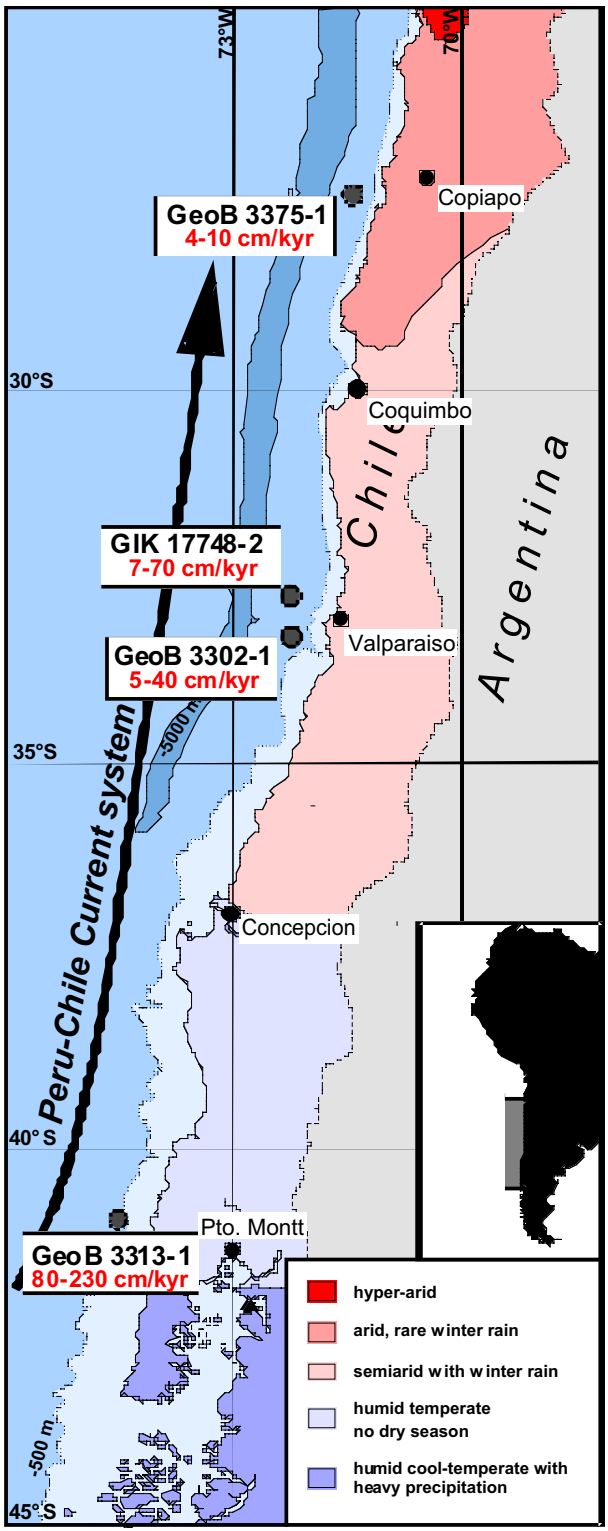

Figure 1: Location of sediment cores along the Chilean continental margin in relation to the present climate zonation. Sedimentation rates and thus the time resolution of the paleoclimate records increase strongly to the south. little attention has been paid so far to the marine paleoclimate record present in continental margin sediments along the west coast of southern South America.

In 1995 a coring expedition by the University of Bremen using the German RV Sonne retrieved sediment cores and surface samples from the Chilean continental slope between ca. $25^{\circ} \mathrm{S}$ and $45^{\circ} \mathrm{S}$. Several studies on both the paleoceanographic history of the Peru Chile Current (Hebbeln et al., in press; Marchant et al., 1999) and the paleoclimates of adjacent Chile (e.g., Lamy et al., 1998a) have been completed or are in in preparation.

The present climate of Chile is characterized by a strong latitudinal gradient of rainfall extending from hyperarid conditions in the Atacama desert of northern Chile through semiarid Mediterranean type conditions in central Chile to extremely high rainfall in the mountains of southern Chile. This climate zonation is principally controlled by the position of the southern westerly storm tracks (Southern Westerlies). It has been known since the early studies by Scholl et al. (1970) that the amount of terrigenous sediment supplied to the Chilean continental margin is related to the strong increase in onshore precipitation from north to south. Therefore, sedimentological analyses of the terrigenous fraction of marine sediments, supplied by rivers and wind to the ocean in this area, provide a unique tool to study continental climate in the past. Based on sedimentological background obtained by the analysis of surface samples (Hebbeln et al., 2000; Klump et al., submitted; Lamy et al., 1998b), terrigenous signals in marine sediments, e.g., source areas, weathering conditions, and mode of sediment input, can clearly be related to the climatic zonation and allow its reconstruction in the past. Due to the presence of planktic foraminifera, Chilean continental margin sequences provide good potential for dating, both by ${ }^{14} \mathrm{C}$ AMS and $\delta^{18} \mathrm{O}$ isotope stratigraphic methods, which are often more accurate than dating of terrestrial sequences.

Due to the large differences in the amount of supplied terrigenous material (see sedimentation rates in Fig. 1), our sediment cores allow past climate reconstructions on different time-scales.
We can now provide a consistent picture of the history of shifts of the Southern Westerlies ranging from millenial timescale Milankovitch precession-driven insolation changes during the last 120,000 years, to decadal time-scales within the Holocene.

Off the Chilean Norte Chico (ca. 27º $\mathrm{S}$ ) (Fig. 1), we find strong evidence for precession-controlled shifts of the Southern Westerlies (Lamy et al., 1998a) resulting in more humid intervals in the Andes of this region roughly every 20,000 years (Fig. 2a). This record suggests more humid conditions during the Last Glacial Maximum (LGM) coinciding with a precession maximum, i.e. a summer insolation maximum in the Southern Hemisphere. More humid LGM climates have also been recently reconstructed for the Bolivian (Thompson et al., 1998) and Peruvian Altiplano (Seltzer et al., 2000). However, in the Altiplano region precipitation is clearly dominated by tropical summer rain, whereas north of the Atacama Desert, winter rain is rare today. In addition there are no indications for tropical moisture influx crossing the South American arid diagonal zone in the past. Therefore, the humid intervals in the Chilean Norte Chico are clearly caused by increased winter rain due to a more northward location of the Southern Westerlies. We estimate a northward shift of ca. $5^{\circ}$ latitude for precession maxima including the LGM. Besides showing dominantly precession driven rainfall changes over the Andes, the records also reveal millennial-scale changes in weathering intensity over the Chilean Coastal Range most likely induced by changes in coastal fog occurrences (Lamy et al., in press). As the frequency and intensity of the so-called 'Camanchacas' along the Chilean coast are today also related to the position of the Southern Westerlies, our record indicates rapid latitudinal shifts of this wind belt throughout at least the last 80,000 years with a similar pattern to rapid climate changes recorded in Greenland ice cores and North Atlantic sediments.

Further south, off central Chile (ca. $33^{\circ} \mathrm{S}$ ), higher sedimentation rates (Fig. 1) allow reconstruction of the climate evolution of the last ca. 30,000 years in more detail (Lamy et al., 1999). Here we also 
Figure 2: Iron content (Fe/ Al ratios measured by ICP-AES spectroscopy, Fe intensity measured with a CORTEX X-ray fluorescence scanner) as a proxy for changes in the terrigenous sediment supply related to rainfall changes induced by latitudinal shifts of the Southern Westerlies. Off northern Chile $\left(27^{\circ} \mathrm{S}\right)$ more humid intervals are characterized by the input of iron-rich material from the Andes. Off central and southern Chile $\left(33^{\circ} \mathrm{S}\right.$ and $\left.41^{\circ} \mathrm{S}\right)$ the Andean material is diluted by iron-poor material derived from the Coastal Range during more humid phases.

find clear evidence for more humid conditions during the LGM. The deglaciation is characterized by a trend towards a more arid climate culminating during the middle Holocene (8000-4000 cal yr $\mathrm{BP})$. The late Holocene was marked by variable climate with generally more humid conditions (Fig. 2b).

This Holocene long-term trend can also be found off southern Chile $\left(41^{\circ} \mathrm{S}\right)$ (Fig. 1) where extremely high sedimentation rates allow a reconstruction of latitudinal shifts of the Southern Westerlies at decadal time-scales (Fig. 2c). Most of the multi-centennial to millennial scale latitudinal shifts appear to be related to climate changes in the North Atlantic region (e.g., Bianchi \& McCave, 1999; Bond et al., 1997) whereas climate variability on centennial to decadal timescales might partly be related to the El Niño-Southern-Oscillation which significantly affects the interannual rainfall variability in mid-latitude Chile (Ruttland \& Fuenzalida, 1991).

Future research will focus on further high resolution studies off central and southern Chile and a comparison of the continental paleoclimate record and the paleoceanographic changes in the Peru-Chile current system. A new coring expedition in spring 2001 promises to retrieve further sediment cores especially from the southern Chilean continental margin with its extremely high sedimentation rates.

\section{References:}

Bianchi, G. G. \& I.N. McCave, Nature 397, 515-517, 1999.

Bond, G. et al. Science 278, 1257-1266, 1997.

Hebbeln, D. et al. Zeitschrift für Angewandte Geologie, in press.

Hebbeln, D. et al. Marine Geology 164, 119-137, 2000.

Klump, J. et al. Submitted to Marine Geology.

Lamy, F. et al. Palaeogeography, Palaeoclimatology, Palaeoecology 141, 233-251, 1998a.

Lamy, F. et al. Geologische Rundschau 87, 477-494, $1998 b$.

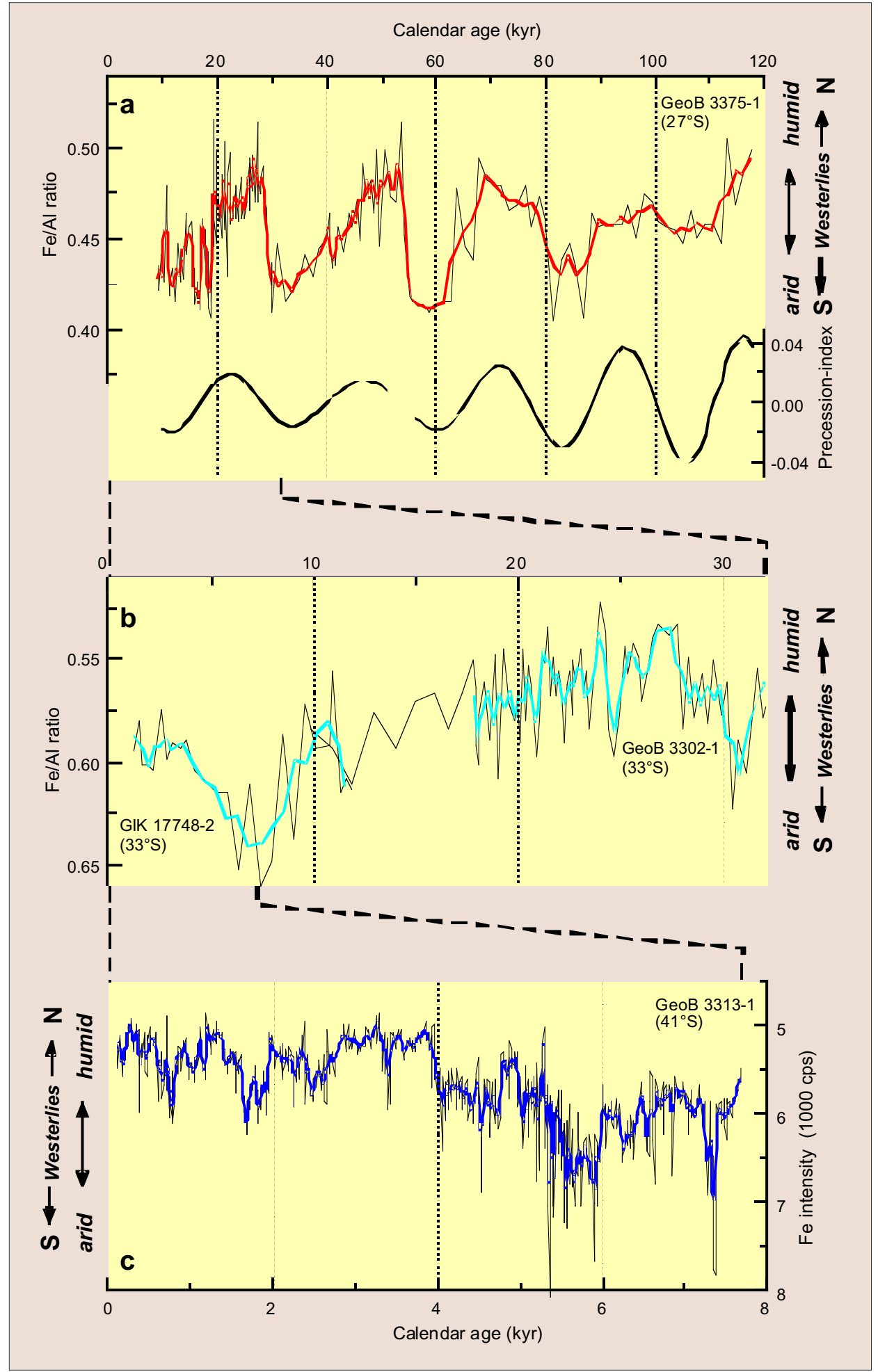

Lamy, F. et al. Quaternary Research 51, 83-93,

$$
1999 .
$$

Lamy, F. et al. Terra Nova, in press

Lamy, F. et al. Submitted to Geology.

Marchant, M. et al. Marine Geology 161, 115-128, 1999.

Markgraf, V. et al. Quaternary Science Reviews 19, 2000.

Ruttland, J. \& H. Fuenzalida. International Journal of Climatology 11, 63-76, 1991.

Scholl, D. W. et al. Geological Society of America Bulletin 81, 1339-1360, 1970.

Seltzer, G.O. et al. Geology 28, 35-38, 2000.
Thompson, L. G. et al. Science 282, 1858-1864, 1998.

Frank Lamy, Dierk Hebbeln \& Gerold Wefer

Fachbereich Geowissenschaften, Universität Bremen, Bremen, Germany

frankl@allgeo.uni-bremen.de

\section{Margarita Marchant}

Depto. Zoologia, Fac. Ciencas Naturales y Oceanográficas, Universidad de Concepción, Concepción, Chile 